\title{
Clustering Based Loading That is Bit Making Use of Neural Sites
}

\author{
S. Sangeetha, R. Kavitha, C. Anuradha, S. Pothumani
}

\begin{abstract}
A simple and easy clustering based loading that is bit is proposed $h$ ere. In Wireless and mobile phone correspondence, there are two main parameters which can be essential be viewed i.e. the power requirement during the transmitting end and s peed of transmission. For do wnlink power that is appreciable be provided as it requires destination from Base $S$ tation to Cellphone individual however the uplink runs on batteries. As an overall total outcome power use should $b$ age optimized. The transmitter power may be minimized if bits are correctly allocated. Our paper is aimed at transmitting target range bits with less power. All of the algorithms for loading bits are iterative in nature, so we ought to aim at reducing the real range iterations. The bit transmission normally followed by wait that should be minimized by optimal allocation of bits with less iteration. The paper is aimed at clustering the sub-channels then allocating $t$ he bits for minimizing iterations. The clustering is d that is performe Neural companies. The proposed algorithms are faster and convergent towards the solution that is optimal.
\end{abstract}

KEYWORDS::OFDM, DMT, little Loading, Neural Networks, Bit ErrorPrice

\section{INTRODUCTION}

A signal can just take mu ltip le paths to visit from $t$ rans mitter to receiver in a wire les s interaction network. We could us e either scarrie that is ingle modulation or Multicarrier Modulation (MCM) for co mmunication. But incas age of solitary carrie $r$ Modulation Frequency Selective Fad ing happens. To have effectiveness in communicat ion we get for Multi carrie $r$ modulation.

In single provider modulation, then frequency s elective fading happens in the event that channel bandwidth is more than the coherence bandwidth . Coherence bandwidth of a channel is the bandwidth upto that the regularity res pons age is flat or cons tant. Hence comp le $\mathrm{x}$ equalizat ion is needed in the cas age of $s$ carrie $r$ modulation that is ingle. In purchase to overcome this, mu lticarrie $r$ modulation is used.

$$
\Delta \mathrm{f}=\mathrm{B} / \mathrm{N}
$$

The entire channel bandwidth is split among various s ubcarriers $\mathrm{s}$ uch that the bandwidth of each $\mathrm{s}$ ubcarrier becomes les $\mathrm{s}$ than the coherence bandwidth ergo going

Revised Manuscript Received on July 22, 2019

S.Sangeetha, Department ofCSE, Bharath Institute of Higher Education and Research, Chennai, Tamilnadu, India.

R.Kavitha, Department of CSE, Bharath Institute of Higher Education and Research, Chennai, Tamilnadu, India.

C. Anuradha, Department of CSE, Bharath Institute of Higher Education and Research, Chennai, Tamilnadu, India.

S. Pothumani, Department of CSE, Bharath Institute of Higher Education and Research, Chennai, Tamilnadu, India. from regularity s elective diminishing to flat diminishing in multicarriermodulation.

where $\mathrm{N}$ is the quantity of $\mathrm{s}$ ubcarriers, $\mathrm{B}$ is the bandwidth that is total of channel and $\Delta \mathrm{f}$ may be the $\mathrm{s}$ ubcarrier bandwidth.

Then flat fading happens if $\delta \mathrm{f}<<\mathrm{Bc}$ (coherence bandwidth .Als o Inter Symbol Interference is almos $t$ minimal and therefore no equalization is needed in the cas e of multicarriermodulation. The two mos t typical kinds of Mult i-Carrier ion that is modulat OFDM (Orthogonal regularity Divis ion numerous xing) and DMT (Dis crete Multi-tone Modulation). OFDM is generally speaking us ed in Audio Broadcas ting whereas DMT discovers application in telecommunications over As ymmetric Dig ital Subs criber Lines (ADSL). Un like OFDM where all s ub-channels are ass igned with s ame nu mber of bits, DMT as s igns bits bas ed on Signal to Nois e ratios of s ub-channels. DMT is adaptive OFDM with little Loading.For every ubcarrier that is s we now have individual gains. There are a couple of forms of modulation for MCM in other words. fixed modulation and modulations which can be adaptive. Fixed Modulation is us ed whenever the channel conditions are almos cons which are $t$. In this cas age hanges which are $\mathrm{c}$ the channel may not be tolerated. Adaptive Modulation is us ed whenever channel conditions are adjustable. In thes age cases alterations in thehannel that is $\mathrm{c}$ allocation of more networks and bits could be cared for. The a lgorith $\mathrm{m}$ a llocates $\mathrm{s}$ ub companies to $\mathrm{s}$ being brand new stations. This will be a s being practical.

\section{BIT LOADING}

Bit Loading is a method in which bit allocation isdone for the $\mathrm{s} u b$-carriers in Multicarrie r Modulation like DMT. The bits allocation is bas ed in the s ub channel quality which is bas ed on parameters like SNR. The aim of this method is always to allocate more bits to stations with a high SNR or low corrupted networks and less bits to stations with low SNR or extremely corrupted networks .[1]-[6]

Little Loading involves allocation of para meters like Energyand the bits to a sub channel. The para meters taken into consideration while allocating the above mentioned parameters being mentioned Sub-channel Gain $(H)$, Sub -channel Nois e(N), SNR gap $(\Gamma)$, Target Bits (Btotal), Maximu m Energy(Ptotal),TargetMargin(tm). All thealgorithms take fe $\mathrm{w}$ of the above talked about parameters under consideration to propos e an optima s which are 1 for little Loading.

The most powerful approach to allocate bits with less power is us ing Hughes -Hartogs Greedy Algorithm nonetheless it takes lots that is big of rations to converge to 
the optimal s olution.[9] Chow's Algorith m us es channel ability approximation andconverges to your s olution for provided target bits and gratification ma rgin.[3] Campello's Algorithm is $d$ ifferen $t$ into the method it takes age that is differential to attain the target bits .[5] But both thes age algorithms simply take a whole great deal of iterations .

The SNR for a s ub-channel is distributed by

$$
\mathrm{SNR}=|\mathrm{H}| 2 /(\Gamma . \sigma 2) \quad(2)
$$

Where SNR ap that is $\mathrm{g} \Gamma$, represents exactly how far is the $\mathrm{c}$ hannelfro mShannon Channel Ability.

To lessen iteration co mplexity among the techniques is ter that is clusgroup $\mathrm{s}$ ub-channels bas ed on their gain res pons age. This method leads to cluster by team bit loading which jus t takes one iteration to allocate bits but for grouping iterations are

Required,[2 that is.[1] The nu mber of teams is provided by

$$
\text { Gr oups }=\log 2(|\mathrm{Hmax}| 2 /|\mathrm{Hmi} \mathrm{n}| 2)+1
$$

Where Hma $\mathrm{x}$ and Hminare maximu min and $\mathrm{m}$ imu $\mathrm{m}$ regarding the gains associated with s ub-channels. Figure1 shows grouping done bas ed on sub-channel gains . [15, 16, 17].

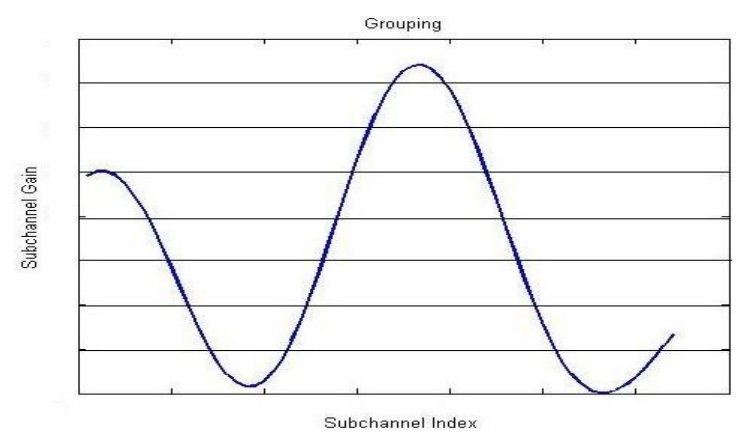

Figure1: Grouping of Sub-Channels

\section{NEURAL NETWO RKS}

Us e ac tivation function to upgradeBas ed on above algorithm, for every single iteration we get $\mathrm{s}$ ome $\mathrm{s}$ ub-channels in an organization. Whenever all teams are filled the $\mathrm{b}$ its are allocated to each $\mathrm{s} u b$-channel, allocating $\mathrm{s}$ ame bits to every s ub-channel in a particula $r$ team. The Algorith $\mathrm{m}$ is s hown in Figure 2.

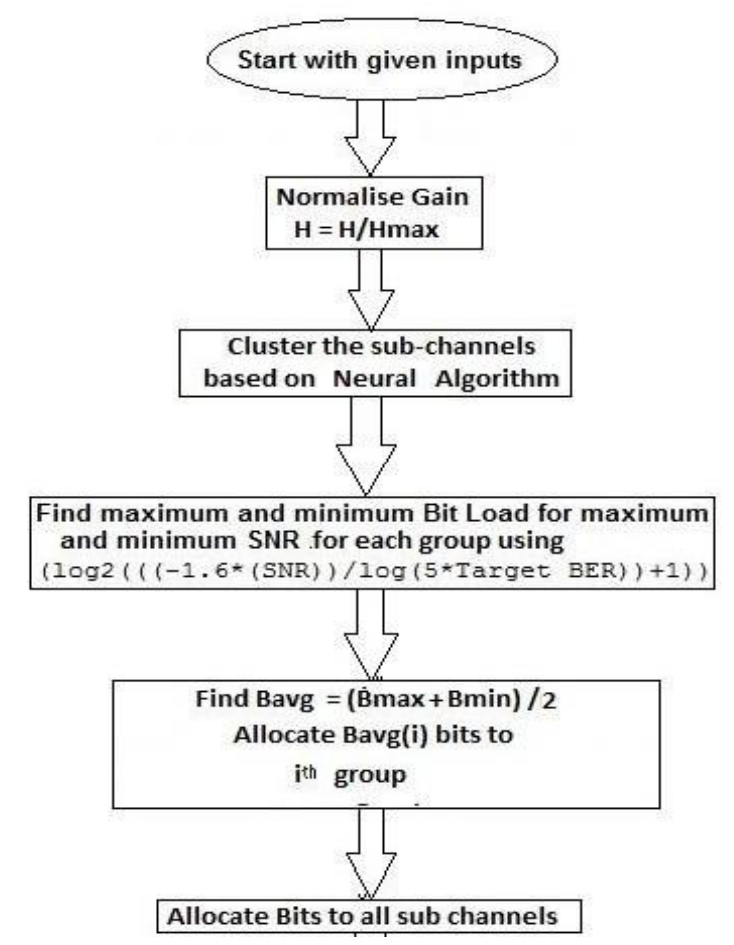

Figure 2: Algorithm Diversescription Flo wchart

Finally the Bits are curved down us ing provided target bits and also the bits presently allocated. [18, 19, 20]. The target bits can be performed us ingNeural companies are us ed for optimization of res ults . There are two main forms of Learning in Neural NetworksSupervis that ised(4)Unsupervis ed. Supervised Neural companies require a databas age to get or predict the production for a s input that is pecified the BPN (Bac k Propagation system). [21, 22, 23]. Unsupervised Learning do not need to require learning that is prior. The Competitive understand ing is an Unsupervised Learning. Th is is bas ed regarding the basic idea'Winner just take s all approach'. Co mpetitive Lea rning includes Max web, Me xican Hat, Ha mming web and Self Organising Maps. Thes age Nets could be us ed to cluster the info input, right here $s$ ub - stations. For the nets we've various activation functions. Max web, Me xican Hat and Ha mming web a re Fixed Weight Co Lea rning that is competitive practices $[24,25,26]$.

\section{CLUSTERING BASED BIT LOADING USING NEURAL NETWO RKS}

For simulation purpose e the input information includes 64 sub - stations. The gain res pons age is produced using a 3 faucet -filter(Figure 3). The prospective BER is taken as 10-5. Noisage variance is 0.001 . The prospective Bits are taken to be $400[27,28]$. 


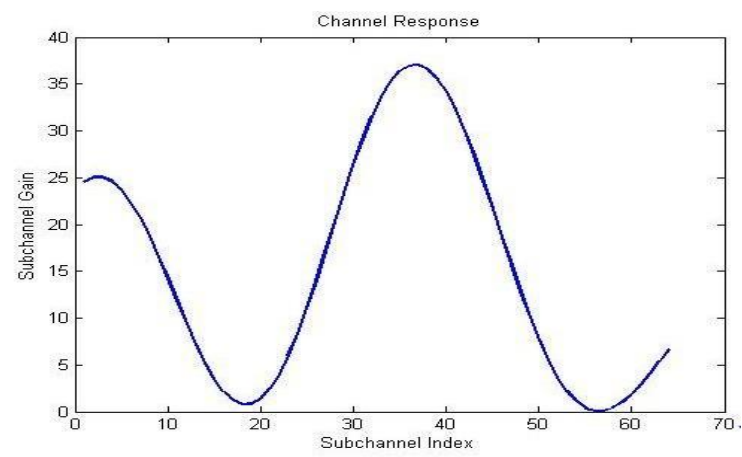

Figure 3: Sub-Channel Response age

\section{A. Max Web}

A co that is particular net that does winner takes -all competition is the Maxnet. In this system learning is perhaps notcons idered as an essential requirements.[7] A $n$ s which are eural is offered [29, 30].

which achieves champion takes all co mpetit ion. It pic ks the node whos e input is larges $t$ and therefore it may behave as subnet. It generally does not have training algorith $\mathrm{m}$. The loads us ed listed below are fixed. Bit allocation us ing Ma $\mathrm{x}$ Net is offered in Figure4.

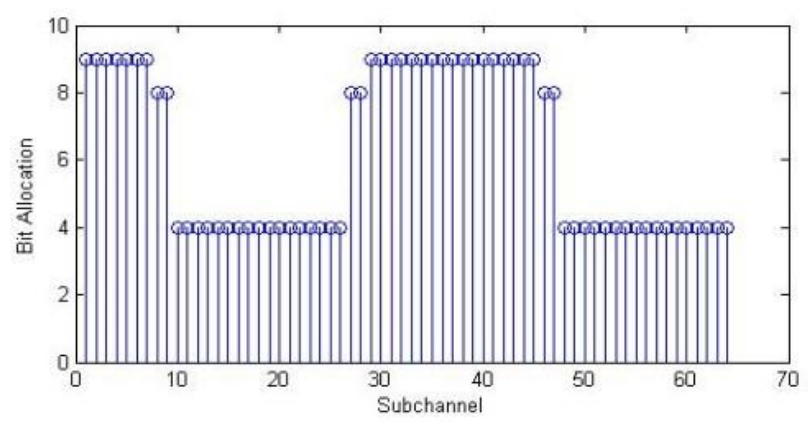

Figure 4: Ma x web Bas ed loading that is bit

\section{B. Mexican Hat}

Mexican Hat is on-center-off s comparison improvement that is urround. Each neuron is linked with excitatory links and lin that is inhibitory to lots of "cooperative next-door neighbors " neurons. Positively weighted links are excitatorylinks and adversely weighted links are inhibitory links. There may als o be a genuine amount of neurons, further away still, to which neuron is maybe not linked. So the neuron gets externa $1 \mathrm{~s}$ ignal in order to connect thos age neurons which are further. For every single neuron the pattern of interconnections is duplicated [29, 30, 31]. The loads are calculated bas ed on range teams discovered us ing (3). Bit Loading us ing Hat that is mexican is hown in Figure5.

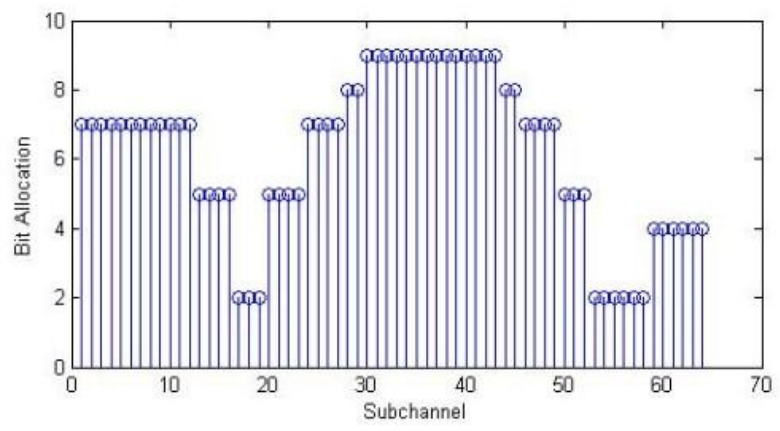

Figure 5: me personally xican Hat Bas ed loading that is bit

C. Self Maps that is arranging(SOM groups the input information into groups .Clustering method is mos $t$ commonly used for unsupervised training. The winning unitparticipate in the lea rningproces $\mathrm{s}$ in SOM all of the devices within the neighbourhood that enjoy positive feedback fro $\mathrm{m}$. Weight vector shall a lways change in res pons e to input vector irrespective of a we ight $\mathrm{v}$ ector being orthogonal to the input vector. The group device whos age weight vector fits $t$ he input pattern clos ely is $s$ elected once the champion. The neighbouring and devices which are winning update their loads . The training provided fors imulation is 0.2.[8]. Figure6 $\mathrm{s}$ hows the bit allocation us ing $\operatorname{SOM}[33,34,35]$.

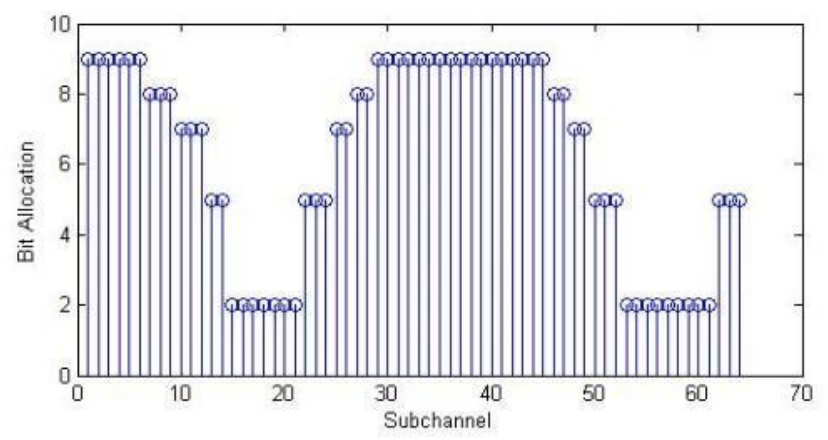

Figure 6: SOM bas ed load ing that is bit

We could als o re move channel that is bad the channels present in group with minimu mains by allocating them no bits during the price of energy which increases proportionally with loaded bits. That is s hown in Figure7.

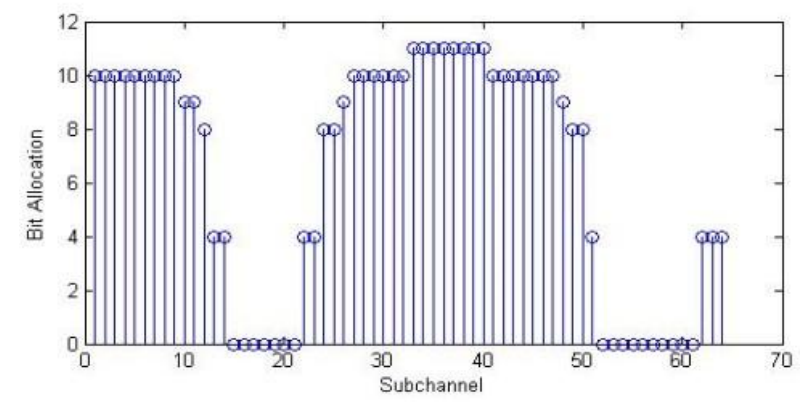

Figure 7: SOM based loading that is bit Bad ChannelRemoval 
Bit Loading is done by finding ma ximu $\mathrm{m}$ and minimu $\mathrm{m}$ $\mathrm{b}$ its which can be packed for the reason that combined group us ing ma ximu $\mathrm{m}$ and minimu $\mathrm{m}$ Channel $\mathrm{Ga}$ in values into the equation

$\mathrm{B}=\left(\log 2\left(-1.6 * \mathrm{SNR} / \log \left(5^{*}\right.\right.\right.$ Target $\left.\left.\left.\mathrm{B} \mathrm{ER}\right)\right)+1\right)$

The power for a s ub-channel is provided by

$$
\mathrm{E}=(2 \mathrm{BL}-1) *(\Gamma . \sigma 2 /|\mathrm{H}| 2)
$$

Where BL may be the bits which can be packed the $\mathrm{s}$ ub -channel and $\sigma 2$ is Nois ageVariance. Finally mistake that is bit, BER is provided by,

$$
\mathrm{B} \mathrm{ER}=0.2 \exp (-1.6(\mathrm{E} /(2 \mathrm{BL}-1))|\mathrm{H}| 2 / \sigma 2))
$$

\section{COMPARISON AND CONCLUSION}

Compared to Hughes Hartogs optima s which are 1, clustering

based algorithm using sites that are neural only 1 iteration for bit allocation and few iterations for grouping. As a res iteration that is ultlexity is paid down. [36, 37, 38]. The ssolution is convergent that is almost $t$ the optima $1 \mathrm{~s}$ solution with just a little higher energy but paid off wide range of iterations. The proposed algorithms are sub optimal but beneficial in terms of iterations

\begin{tabular}{|c|c|c|}
\hline Algorithm & $\begin{array}{c}\text { Allocation } \\
\text { Iteration }\end{array}$ & $\begin{array}{c}\text { Grouping } \\
\text { Iteration }\end{array}$ \\
\hline $\begin{array}{c}\text { Hughes-Hartogs } \\
\text { Algorithm }\end{array}$ & $\mathrm{N}^{*}$ TargetBits & - \\
\hline $\begin{array}{c}\text { ProposedMaxNet } \\
\text { Based }\end{array}$ & 1 & $\mathrm{~N}^{*}$ groups \\
\hline $\begin{array}{c}\text { Proposed } \\
\text { Bexican-Hat } \\
\text { Based }\end{array}$ & 1 & ent*groups \\
\hline $\begin{array}{c}\text { ProposedSOM } \\
\text { Based }\end{array}$ & 1 & Userdepend \\
\hline
\end{tabular}

Table I: Dining table we: Nu mber of Iterat ions taken for loading bits by different

Compared to Max web and mexican bas which are hat grouping, SOM res ults s exactly how better allocation. More over in SOM wide range of grouping iterations is perhaps not fixed, can be determined by us er. (TableII) [39, 40, 41].

Input

\begin{tabular}{|c|c|c|}
\hline Algorithm & Energy(Joule & Iteration \\
\hline $\begin{array}{c}\text { Hughes-Hart } \\
\text { ogs }\end{array}$ & 0.5829 & 25 \\
$6 n$ \\
\hline $\begin{array}{c}\text { ProposedMaxN } \\
\text { et }\end{array}$ & 5.6239 & 6 \\
\hline $\begin{array}{c}\text { ProposedMexic } \\
\text { an- }\end{array}$ & 3.1482 & 6 \\
\hline $\begin{array}{c}\text { ProposedSO } \\
\text { M }\end{array}$ & 3.3551 & 4 \\
\hline
\end{tabular}

Table II: Energy and Iteration Comparison for offered Simulation

The dining table s hows that at the expensive of power (maybe not much s change that is significant we are able to make our algorithms faster by reducing the quantity of iterations . Ergo we can go with these e s ub-optima 1 algorithms to minimize iteration complexity.

\section{REFERENCES}

1. Kumarave A., Rangarajan K.,Algorithm for automaton specification for exploring dynamic labyrinths,Indian Journal of Science and Technology,V-6,I-SUPPL5,PP-4554-4559,Y-2013

2. P. Kavitha, S. Prabakaran "A Novel Hybrid Segmentation Method with Particle Swarm Optimization and Fuzzy C-Mean Based On Partitioning the Image for Detecting Lung Cancer" International Journal of Engineering and Advanced Technology (IJEAT) ISSN: 2249-8958, Volume-8 Issue-5, June 2019

3. Kumaravel A., Meetei O.N.,An application of non-uniform cellular automata for efficient cryptography,2013 IEEE Conference on Information and Communication Technologies, ICT 2013,V-,I-,PP-1200-1205,Y-2013

4. Kumarave A., Rangarajan K.,Routing alogrithm over semi-regular tessellations,2013 IEEE Conference on Information and Communication Technologies, ICT 2013,V-,I-,PP-1180-1184,Y-2013

5. P. Kavitha, S. Prabakaran "Designing a Feature Vector for Statistical Texture Analysis of Brain Tumor" International Journal of Engineering and Advanced Technology (IJEAT) ISSN: 2249-8958, Volume-8 Issue-5, June 2019

6. Dutta P., Kumaravel A.,A novel approach to trust based identification of leaders in social networks,Indian Journal of Science and Technology,V-9,I-10,PP--,Y-2016

7. Kumaravel A., Dutta P.,Application of Pca for context selection for collaborative filtering,Middle - East Journal of Scientific Research,V-20,I-1,PP-88-93,Y-2014

8. Kumaravel A., Rangarajan K.,Constructing an automaton for exploring dynamic labyrinths,2012 International Conference on Radar, Communication and Computing, ICRCC 2012,V-,I-,PP-161-165,Y-2012

9. P. Kavitha, S. Prabakaran "Adaptive Bilateral Filter for Multi-Resolution in Brain Tumor Recognition" International Journal of Innovative Technology and Exploring Engineering (IJITEE) ISSN: 2278-3075, Volume-8 Issue-8 June, 2019

10. Kumaravel A.,Comparison of two multi-classification approaches for detecting network attacks, World Applied Sciences Journal,V-27,I-11,PP-1461-1465,Y-2013

11. Tariq J., Kumaravel A.,Construction of cellular automata over hexagonal and triangular tessellations for path planning of multi-robots,2016 IEEE International Conference on Computational Intelligence and Computing Research, ICCIC 2016,V-,I-,PP--,Y-2017

12. Sudha M., Kumaravel A.,Analysis and measurement of wave guides using poisson method,Indonesian Journal of Electrical Engineering and Computer Science,V-8,I-2,PP-546-548,Y-2017

13. Ayyappan G., Nalini C., Kumaravel A.,Various approaches of knowledge transfer in academic social network,International Journal of Engineering and Technology,V-,I-,PP-2791-2794,Y-2017

14. Kaliyamurthie, K.P., Sivaraman, K., Ramesh, S. Imposing patien data privacy in wireless medical sensor networks through homomorphic cryptosystems 2016, Journal of Chemical and Pharmaceutical Sciences 92.

15. Kaliyamurthie, K.P., Balasubramanian, P.C. An approach to multi secure to historical malformed documents using integer ripple transfiguration 2016 Journal of Chemical and Pharmaceutical Sciences 92.

16. A.Sangeetha,C.Nalini,"Semantic Ranking based on keywords extractions in the web", International Journal of Engineering \& Technology, 7 (2.6) (2018) 290-292

17. S.V.GayathiriDevi,C.Nalini,N.Kumar,"An efficient software verification using multi-layered software verification tool "International Journal of Engineering \& Technology, 7(2.21)2018 454-457

18. C.Nalini,ShwtambariKharabe,"A Comparative Study On Different Techniques Used For Finger - Vein 
Authentication", International Journal Of Pure And Applied Mathematics, Volume 116 No. 8 2017, 327-333, Issn: 1314-3395

19. M.S. Vivekanandan and Dr. C. Rajabhushanam, "Enabling Privacy Protection and Content Assurance in Geo-Social Networks", International Journal of Innovative Research in Management, Engineering and Technology, Vol 3, Issue 4, pp. 49-55, April 2018.

20. Dr. C. Rajabhushanam, V. Karthik, and G. Vivek, "Elasticity in Cloud Computing", International Journal of Innovative Research in Management, Engineering and Technology, Vol 3, Issue 4, pp. 104-111, April 2018.

21. K. Rangaswamy and Dr. C. Rajabhushanamc, "CCN-Based Congestion Control Mechanism In Dynamic Networks", Internationa Journal of Innovative Research in Management, Engineering and Technology, Vol 3, Issue 4, pp. 117-119, April 2018.

22. Kavitha, R., Nedunchelian, R., "Domain-specific Search engine optimization using healthcare ontology and a neural network backpropagation approach", 2017, Research Journal of Biotechnology, Special Issue 2:157-166

23. Kavitha, G., Kavitha, R., "An analysis to improve throughput of high-power hubs in mobile ad hoc network" , 2016, Journal of Chemical and Pharmaceutical Sciences, Vol-9, Issue-2: 361-363

24. Kavitha, G., Kavitha, R., "Dipping interference to supplement throughput in MANET", 2016, Journal of Chemical and Pharmaceutical Sciences, Vol-9, Issue-2: 357-360

25. Michael, G., Chandrasekar, A.,'Leader election based malicious detection and response system in MANET using mechanism design approach", Journal of Chemical and Pharmaceutical Sciences(JCPS) Volume 9 Issue 2, April - June 2016.

26. Michael, G., Chandrasekar, A.,"Modeling of detection of camouflaging worm using epidemic dynamic model and power spectral density", Journal of Chemical and Pharmaceutical Sciences(JCPS) Volume 9 Issue 2, April - June 2016.

27. Pothumani, S., Sriram, M., Sridhar, J., Arul Selvan, G., Secure mobile agents communication on intranet,Journal of Chemical and Pharmaceutical Sciences, volume 9, Issue 3, Pg No S32-S35, 2016

28. Pothumani, S., Sriram, M., Sridhar, Various schemes for database encryption-a survey, Journal of Chemical and Pharmaceutical Sciences, volume 9, Issue 3, Pg NoS103-S106, 2016

29. Pothumani, S., Sriram, M., Sridhar, A novel economic framework for cloud and grid computing, Journal of Chemical and Pharmaceutical Sciences, volume 9, Issue 3, Pg No S29-S31, 2016

30. Priya, N., Sridhar, J., Sriram, M. "Ecommerce Transaction Security Challenges and Prevention Methods- New Approach” 2016 ,Journal of Chemical and Pharmaceutical Sciences, JCPS Volume 9 Issue 3.page no:S66-S68 .

31. Priya, N.,Sridhar,J.,Sriram, M.“Vehicular cloud computing security issues and solutions" Journal of Chemical and Pharmaceutical Sciences(JCPS) Volume 9 Issue 2, April - June 2016.

32. Priya, N., Sridhar, J., Sriram, M. "Mobile large data storage security in cloud computing environment-a new approach" JCPS Volume 9 Issue 2. April - June 2016

33. Anuradha.C, Khanna.V, "Improving network performance and security in WSN using decentralized hypothesis testing "Journal of Chemical and Pharmaceutical Sciences(JCPS) Volume 9 Issue 2, April - June 2016 .

34. Anuradha.C, Khanna.V, "A novel gsm based control for e-devices" Journal of Chemical and Pharmaceutical Sciences(JCPS) Volume 9 Issue 2, April - June 2016

35. Anuradha.C, Khanna.V, "Secured privacy preserving sharing and data integration in mobile web environments "Journal of Chemical and Pharmaceutical Sciences(JCPS) Volume 9 Issue 2, April - June 2016.

36. Sundarraj, B., Kaliyamurthie, K.P. Social network analysis for decisive the ultimate classification from the ensemble to boost accuracy rates 2016 International Journal of Pharmacy and Technology 8

37. Sundarraj, B., Kaliyamurthie, K.P. A content-based spam filtering approach victimisation artificial neural networks 2016 International Journal of Pharmacy and Technology $8 \quad 3$.

38. Sundarraj, B., Kaliyamurthie, K.P. Remote sensing imaging for satellite image segmentation 2016 International Journal of Pharmacy and Technology $8 \quad 3$

39. Sivaraman, K., Senthil, M. Intuitive driver proxy control using artificial intelligence 2016 International Journal of Pharmacy and Technology 84.

40. Sivaraman, K., Kaliyamurthie, K.P. Cloud computing in mobile technology 2016 Journal of Chemical and Pharmaceutical Sciences 92.

41. Sivaraman, K., Khanna, V. Implementation of an extension for browser to detect vulnerable elements on web pages and avoid click

jacking 2016 Journal of Chemical and Pharmaceutical Sciences 9
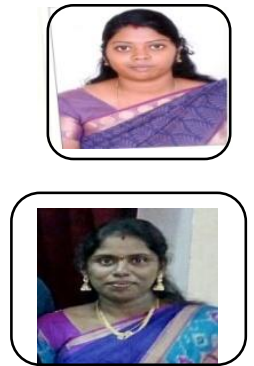

R. Kavitha, Associate Professor, Department of Computer Science and Engineering, Bharath Institute of Higher Education and Research, Chennai, India.

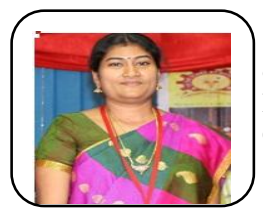

C.Anuradha, Assistant Professor, Department of Computer Science and Engineering, Bharath Institute of Higher Education and Research, Chennai.

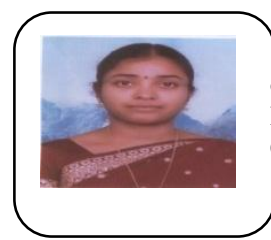

S.Pothumani, Associate Professor, Department f Computer Science and Engineering, Bharath nstitute of Higher Education and Research, Chennai, India. 